\title{
Opiskelijan resurssit ja etenemisen haasteet sivutoimisissa jatko-opinnoissa
}

MIIA MARTINSUO \& VEIKKO TEIKARI

\begin{abstract}
Runsaasti jatko-opintokiinnostusta herättävät tutkimusalat joutuvat pohtimaan, kohdistavatko ne toimintansa vain nelivuotisen, nopean ja tehokkaan tutkijanuralle tähtäävän jatkokoulutuksen väylälle vai hyväksyvätkö ja tukevatko ne myös asiantuntijuuttaan syventävien, sivutoimisten "elämäntapaopiskelijoiden" selvästi hitaampaa jatkokoulutuksen väylää. Artikkeli perustuu tutkimukseen, jossa selvitettiin Teknillisen korkeakoulun Tuotantotalousden osaston sivutoimisten jatko-opiskelijoiden opintojen viivästymistä jatko-opiskelijoiden itsensä kokemina.
\end{abstract}

$\mathrm{J}$ atko-opiskelu on vakiinnuttanut asemansa suomalaisessa yliopistojärjestelmässä. Kuluneen 20 vuoden aikana tohtoritutkintojen vuotuinen määrä on nelinkertaistunut reiluun 1400:aan, kun taas lisensiaatintutkintojen määrä on lähtenyt tasaiseen laskuun 1990-luvun lopun huipustaan (Opetusministeriön KOTA-tietokanta). Jatko-opintokiinnostuksen lisääntymiseen ovat myötävaikuttaneet mm. tutkijakoulujen ja muiden rahoitusmahdollisuuksien lisääntyminen (Opetusministeriö 2006a, Hiltunen ja Pasanen 2006, Dill et al. 2006, Vuolanto ja Pasanen 2007), perustutkintojen nopea kehitys, opetus- ja tutkimustehtävien laajentunut tarjonta sekä kansainväliset vaikutteet (Kivinen et al. 1993).

Jatko-opintojen toteuttamiseen liittyvä järjestelmä ei kuitenkaan ole kehittynyt samaan tahtiin jatko-opiskelijamäärän kasvun kanssa. Muutos on ollut reaktiivista ja tehokkuusorientoitunutta, tieteen vapaus on vaihtunut projektimyllytykseen (Hakala et al. 2003). Opiskelijamäärät ovat kasvaneet, mutta ohjaus- ja opetusresurssit eivät niinkään (Väyrynen 2003). Viime vuosikymmenellä alettiin kiinnittää aiempaa enemmän huomiota jatkokoulutukseen ja sitä seuraavan tutkijanuran kehittämiseen. Huomio on kiinnittynyt paljolti tutkijakoulujen kehittämiseen ja niiden toiminnan tutkimiseen (Opetusministeriö 2006a, b, Tekniikan Akateemisten Liitto TEK 2001, Hiltunen ja Pasanen 2006, Dill et al. 2006, Vuolanto ja Pasanen 2007).
Jatko-opintojen houkuttavuuden eräs lieveilmiö on se, että jatko-opiskelun käynnistää suuri joukko ihmisiä, joista vain osa vie opintonsa tohtorin tai lisensiaatin tutkintoon saakka. Opetusministeriön KOTA-tietokannan mukaan jokaista valmistunutta kohden on ainakin 4-5 keskeneräistä jatko-opiskelijaa, ja tämä arvio saattaa olla puutteellinen etenkin tilastoinnin käynnistymistä edeltäviltä ajoiltaan. Kerran haettu jatko-opinto-oikeus säilyy valmistumiseen tai kuolemaan saakka etenemistahdista riippumatta. Jatkokoulutusjärjestelmän yhteiseksi huoleksi on tullut suuri joukko "hiljaisia” tai "passiivisia” jatko-opiskelijoita (Dill et al. 2006). Jokainen jatko-opinnoissaan etenevä jatko-opiskelija tarvitsee ohjauksellista ja opetuksellista tukea yliopiston henkilökunnalta.

Keskeneräisen jatko-opiskelun runsautta saattaa selittää erilaiset väylät tohtorikoulutukseen. Jatko-opiskelijat voidaan jakaa ammattimaiseen tutkijanuraan tähtääviin ja työelämän muunlaisen ammattipätevyyden kohottamiseen tähtääviin opiskelijoihin. Jatko-opiskelijaksi hakeutuneet voivat tulla suoraan maisterikoulutuksesta, mutta entistä näkyvämmin jatko-opiskelijoiksi hakeudutaan joidenkin työelämävuosien jälkeen ammatillisista tehtävistä (esim. Tekniikan Akateemisten Liitto TEK 2001, Opetusministeriö 2006a, Vuolanto ja Pasanen 2007).

Erilaiset jatko-opiskelijaryhmät poikkeavat toisistaan siinä, onko jatkotutkintoon tähtäävä työ 
päätoimista omistautumista tutkimustyöhön vai sivutoimista varsinaisen ansiotyön ohessa opiskelua. Opetusministeriön tohtorikoulutusta koskeva kehittämisraportti painottaa edelleen tohtorin tutkinnon suorittamista pääsääntöisesti neljässä vuodessa, mutta tunnistaa myös sivutoimisen ja näin ollen selvästi pitempikestoisen jatkotutkimuksen toteutusmahdollisuuden (Opetusministeriö 2006a, myös Hiltunen ja Pasanen 2006). Käytännössä neljän vuoden tavoiteaikataulu on sivutoimisessa jatko-opiskelussa täysin mahdoton, sillä tutkintotavoitteet näille ryhmille ovat samantasoiset ja työelämässä työskentelevien tutkijanvalmiudet ja jatko-opiskeluun käyttämä viikottainen aika voivat olla päätoimista tutkijaa heikommalla tasolla.

Millä tavoin yliopistojen ja niiden eri tutkimusalojen tulisi suhtautua sivutoimisen jatkoopiskelun mahdollisuuteen? Esimerkiksi tekniikan alalla erään tutkimuksen mukaan yli puolet jatkoopiskelijoista tekee jatko-opintojaan sivutoimisesti (Tekniikan Akateemisten Liitto TEK 2001). Etenkin runsaasti jatko-opintokiinnostusta herättävät tutkimusalat joutuvat pohtimaan, kohdistavatko ne toimintansa vain nelivuotisen, nopean ja tehokkaan tutkijanuralle tähtäävän jatkokoulutuksen väylälle. Tällöin jatkokoulutuksen ja sen rahoituksen piiriin etsitään pieni joukko parasta tutkijapotentiaalia neljän vuoden jatkokoulutusohjelmaan. Samalla tutkimusalat joutuvat pohtimaan, hyväksyvätkö ja tukevatko ne asiantuntijuuttaan syventävien, sivutoimisten "elämäntapaopiskelijoiden” selvästi hitaampaa jatkokoulutuksen väylää. Tohtorin- tai lisensiaatintutkinto voi sivutoimisessa jatko-opiskelussa merkitä 10-15 vuoden aikataulua. Jo nyt yliopistojen kirjoilla on tuhansia keskeneräisiä jatko-opiskelijoita, joiden neljän vuoden tavoiteaika on umpeutunut vuosia sitten.

Tämä artikkeli perustuu tutkimukseen, jonka lähtökohtana on tarve kehittää jatkokoulutusta alalla, jolla sivutoimisen, asiantuntijuutta syventävän jatko-opiskelun kysyntä ylittää päätoimisen, tutkijauralle suuntaavan jatko-opiskelun kysynnän. Teknillisessä korkeakoulussa Tuotantotalouden osaston jatkokoulutukseen hakeutuu paljon teollisuudessa työskenteleviä asiantuntijoita ja johtajia, jotka haluavat tehdä jatkotutkintonsa oman ansiotyönsä ohessa sivutoimisesti. Tämä tutkimus keskittyy sivutoimisiin jatko-opiskelijoihin Tuotantotalouden osastolla, jota käytetään esimerkkinä poikkitieteellisestä ja sivutoimisia jatko-opis- kelijoita houkuttavasta alasta. Vaikka aiempi tutkimus keskittyy pääosin nelivuotisiin, tutkijakoulurahoitteisiin ohjelmiin, viime aikoina on havaittu tarve tutkia ja ymmärtää paremmin sivutoimisen jatko-opiskelun erityispiirteitä ja -tarpeita päätoimisen jatko-opiskelun rinnalla (esim. Vuolanto ja Pasanen 2007).

Tutkimuksen tarkoituksena on tunnistaa tekijöitä, jotka selittävät sivutoimisten, jatko-opinnoissaan keskeneräisten (ja neljän vuoden aikatauluun nähden viivästyneiden) jatko-opiskelijoiden kokemuksia opiskelun ja opinnäytetyön etenemisestä. Tavoitteena on lisätä tietoa sivutoimisten jatko-opintojen suunnittelun, ohjauksen ja tuen mahdollisuuksista, kun jatko-opinnot ovat kesken eivätkä etene päätoimisten jatko-opintojen tahtiin. Haluamme osallistua keskusteluun suomalaisen jatkokoulutuksen tilanteesta ja kehitysmahdollisuuksista etenkin siltä osin, kun jatkokoulutus kytkeytyy työelämässä olevien haluun syventää asiantuntemustaan yliopistollisen jatkotutkinnon keinoin. Keskitymme tutkimuksessamme opiskelijoiden omaan ajankäyttöön sekä heidän kokemaansa tukeen.

\section{Tohtoriopintojen resurssit ja resurssien yhteys työn etenemiseen}

Jatko-opiskelijat tarvitsevat opintojensa ja opinnäytetutkimuksensa suorittamiseen omia ja ympäröivän tiedeyhteisön monenlaisia resursseja. Aikaisemmassa tohtoriopintoja koskevassa tutkimuksessa on tarkasteltu ensisijaisesti neljänlaisia jatko-opiskelun resursseja ja niiden yhteyttä työn etenemiseen: opiskelijalla itsellään olevia voimavaroja, opiskelijan jatko-opiskelussa ja opinnäytetyössä käytettävissä olevaa tukea, rahallista tukea (Seagram et al. 1998, Ferrer de Valero 2001, Tekniikan Akateemisten Liitto TEK 2001, Hiltunen ja Pasanen 2006, Vuolanto ja Pasanen 2007) ja ulkopuolisten voimien kuten osaston ominaisuuksien ja vaihtoehtoisiksi koettujen työmahdollisuuksien vaikutuksia (Ferrer de Valero 2001, Golde 1998, 2005). Samankaltaisia viitekehyksiä on käytetty myös perusopintojen sujumista koskevissa tutkimuksissa (esim. Kurri 2006).

Girves ja Wemmerus (1988) ovat esittäneet opintojen etenemisestä käsitteellisen mallin, joka kattaa sekä opiskelijan ominaisuudet että kokemukset osaston henkilökunnasta, osaston ominaisuuksista ja rahallisesta tuesta. Heidän empiirinen tutkimuksensa vahvistaa vain osan näiden 
tekijöiden yhteydestä tutkinnon vaatiman työn edistymiseen. Suomalaiset empiiriset tutkimuksetkin usein käsittelevät em. tekijöitä ja vertailevat taustatekijöiltään erilaisten ryhmien resursseja, tukea ja etenemistä keskenään (Tekniikan Akateemisten Liitto TEK 2001, Hiltunen ja Pasanen 2006, Vuolanto ja Pasanen 2007). Joissakin tutkimuksissa mainitut osa-alueet on sisällytetty erilaisiin yhteensopivuus-käsitteisiin, joita voivat olla esimerkiksi tiedekunnan tai laitoksen ominaisuuksien ja yksilön odotusten välinen yhteensopivuus tai ohjaajan ja opiskelijan (epä-)yhteensopivuus (esim. Golde 2005, Sorenson and Kagan 1967). Tässä tutkimuksessa keskitytään resursseissa opiskelijan lähipiiriin: hänen omiin ajallisiin voimavaroihinsa ja kokemaansa tukeen.

\section{Henkilökohtaiset ominaisuudet, taipumukset ja ajankäyttö}

Jatko-opiskelijan henkilökohtaiset ominaisuudet ja taipumukset ovat tärkeätä jatko-opinnäytteen loppusaattamisessa (Esim. Green 1997, Seagram et al. 1998, Gordon 2003, Stack 2004). Etenkin viivästymiseen johtavia tekijöitä on tarkasteltu paljon. Monia yksilöllisiä perusvalmiuksia on syytä arvioida jo hakeuduttaessa jatko-opintoihin, sillä niihin voi olla erityisen vaikea vaikuttaa myöhemmin.

Opiskelijan taustatekijöistä on käsitelty mm. ikää, aikaa jatko-opintojen aloittamisesta, aikaa perustutkinnon valmistumisesta ja sukupuolta. Tekniikan alalla tehdyssä tutkimuksessa havaittiin, että nuoret ikäryhmät arvioivat valmistuvansa jatko-opinnoista merkittävästi lyhemmässä ajassa kuin vanhemmat ikäryhmät (Tekniikan Akateemisten Liitto TEK 2001). Samassa tutkimuksessa huomattiin lasten määrän olevan yhteydessä arvioituun jatko-opintojen kestoon. Vuolanto ja Pasanen (2007) havaitsivat, että sivutoimiseksi päätyvillä jatko-opiskelijoilla on jo lähtökohtaisesti kulunut pitempi aika maisterintutkinnosta kuin päätoimisilla ja näin ollen heikommat lähtökohdat valmistua nuorena. Naisten tutkimuksessa etenemisen on havaittu olevan miehiä heikompaa mm. lasten syntymisen ja kasvatuksen sekä jatkoopintoihin kohdistuvien erilaisten odotusten vuoksi (Seagram et al. 1998, Stack 2004, Lenz 1997). Naisten ja miesten jatko-opinnoissa kokemasta kehityksestä on saatu myös vastakkaisia tuloksia (ks. esim. Hiltunen ja Pasanen 2006).

Jatko-opiskelijan ominaisuuksia ja taipumuksia on tarkasteltu monin tavoin. Greenin (1997) katsauksessa korostuvat itsetunnon puute, täydellisyy- den tavoittelu ja vitkastelu eli taipumus siirtää työtä tarpeettomasti ajassa eteenpäin. Myös Lenz (1997) keskittyy täydellisyyden tavoitteeseen keskeisenä yksilötason edistymistä hidastavana ilmiönä, joskin hänen tapaustutkimuksessaan perfektionismilla on myönteiset vaikutukset jo väitelleillä ja negatiiviset vaikutukset keskeneräisillä jatko-opiskelijoilla.

Opintoihin käytettyjä ajallisia resursseja on tarkasteltu eri tutkimuksissa eri tavoin. Eräät suomalaiset tutkimukset jaottelevat opiskelijaryhmiä sen mukaan, millaisen rahoituksen varassa opiskelija toimii, liittyykö rahoitus tutkimuksen tekemiseen ja onko opiskelu pää- vai sivutoimista (Hiltunen ja Pasanen 2006, Vuolanto ja Pasanen

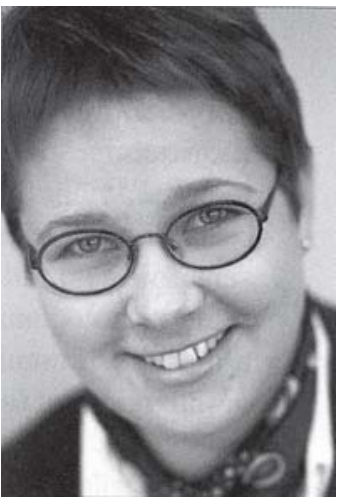

Miia Martinsuo

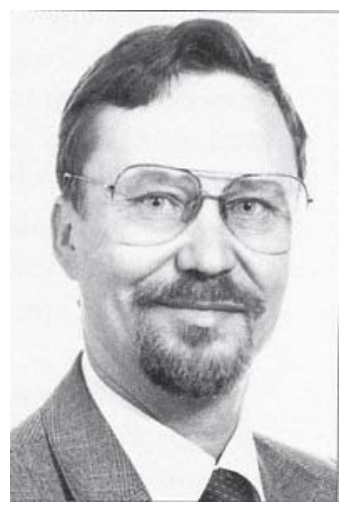

Veikko Teikari 2007). Pää- ja sivutoimisten välillä on löydetty eroja mm. opintojen kestossa, arvioidussa väittelyiässä, tutkinnon etenemisessä, tiedeyhteisöön sosiaalistumisessa ja opintojen lähtökohdissa (Girves ja Wemmerus, Husso 2005, Vuolanto ja Pasanen 2007). Näissä tutkimuksissa päätoimiset etenevät jatkotutkinnossaan sivutoimisia paremmin.

Sivutoimisessa jatko-opiskelussa on havaittu edistymistä hidastavia ongelmia. Tekniikan alalla tehdyssä tutkimuksessa tarkasteltiin jatko-opintoihin käytettyä aikaa ja sen yhteyttä opintojen arvioituun kestoon. Valtaosa eli yli 66 prosenttia laajan kyselyn vastaajista pystyi käyttämään alle päivän verran viikossa aikaansa jatko-opiskeluun, ja niukka ajankäyttö oli yhteydessä pitkäksi arvioituun opintojen kestoon. Tutkimuksessa raportoitiin, että arvioitu opiskeluaika oli lyhin niillä, jotka ilmoittivat käyttävänsä keskimäärin neljä työpäivää viikossa jatko-opintoihinsa (Tekniikan Akateemisten Liitto TEK 2001). Careyn ja Dornin (1998) tapaustutkimuksessa keskityttiin erityisesti täysipäiväistä opetustyötä tekevien, etäopintoina jatko-opintojaan toteuttavien opiskelijoiden kokemukseen jatko-opintojen suorittamisesta. Opetuksen toteutusta tuettiin monin käytännöl- 
lisin keinoin kuten telekonferensseina, sähköposteina ja kurssien järjestämisenä viikonlopuiksi. Opiskelijat kokivat vaikeuksia teknologian käytössä, mutta Careyn ja Dornin artikkelin mukaan esteistä selvittiin monilla vertaisryhmien tukeen liittyvillä keinoilla.

\section{Ohjaus ja tuki}

Jatko-opiskelijan saamaa tukea koskeva tutkimus painottaa ohjaussuhdetta tärkeänä tekijänä työn etenemiselle. Tutkimukset esimerkiksi korostavat, että opiskelijan ja ohjaajan välinen suhde on tärkeässä roolissa jatko-opintojen etenemisen kannalta (Bargar ja Mayo-Chamberlain 1983, Seagram et al. 1998, Aittola ja Määttä 1998, Hiltunen ja Pasanen 2006). Tätä suhdetta voidaan tarkastella sekä ohjaajan että opiskelijan näkökulmasta monin eri tavoin.

Tukea koskevassa tutkimuksessa opiskelijan vuorovaikutus ohjaajansa kanssa sekä yhteys ja sosiaalistuminen akateemiseen ja ammatilliseen yhteisöön ovat tärkeässä roolissa (Bargar ja MayoChamberlain 1983, Aittola ja Määttä 1998, Austin 2002, Weidman ja Stein 2003, Vuolanto ja Pasanen 2007). Tuki voidaan jakaa esimerkiksi korkeakoulun antamaan ohjaukseen, työnantajalta saatavaan ohjaukselliseen tukeen, vertaistukeen ja opiskelijan itseohjauksen. Ohjauksessa oleellista ei ole niinkään ohjaajan tai laitoksen ominaisuudet vaan ohjauksen saatavuus, henkilökohtaisuus ja käytännöt sekä sopivuus opiskelijan tarpeisiin. Suomessa on tutkittu mm. jatko-opintojen ohjauksen eri näkökulmien tärkeyttä, useutta ja riittävyyttä erilaisista näkökulmista ja suhteessa eri taustatekijöihin. (Aittola ja Määttä 1998, Herrala 1999, Tekniikan Akateemisten Liitto 2001, Hiltunen ja Pasanen 2006, Vuolanto ja Pasanen 2007)

Suomalaisissa tutkimuksissa on havaittu, että päätoimiset ja sivutoimiset jatko-opiskelijat tarvitsevat erilaista tukea ja ohjausta. Muualla työelämässä työskentelevät ovat harvemmin kontaktissa yliopiston henkilökuntaan ja vertaisryhmiin, mikä luo uusia haasteita usein päätoimisten opintopolkujen varaan suunnitellulle ohjaukselle. Aikaisempien tutkimustulosten mukaan sivutoimisten jatko-opiskelijoiden on päätoimisiin verrattuna vaikeampi kokea saavansa riittävästi ohjausta, olevansa hyväksyttyjä jäseniä tutkijayhteisössä ja saada opinnoista myönteisiä kokemuksia (Hiltunen ja Pasanen 2006, Vuolanto ja Pasanen 2007). Toisaalta yliopiston ulkopuolinen työyhteisö voi luoda uusia mielekkäitä mahdollisuuksia esimerkiksi oman työpaikan antaman tuen ja opiskelijan yksilöllisen ohjausverkoston muodossa. Yleisesti ottaen tekniikan alan tutkimus kertoo, että opiskelijat ovat melko passiivisia ohjauksen hakemisessa, mikä voi johtua useiden rinnakkaisten ohjauskanavien käytöstä laajemmassa ohjausverkostossa (Tekniikan Akateemisten Liitto TEK 2001, Herrala 1999). Näiden aiempien tutkimusten havainnot kannustavat kehittämään systemaattista, suunnitelmallista ohjausmallia myös sivutoimisille opiskelijoille.

Myös muut emotionaalisen ja sosiaalisen tuen muodot on koettu tärkeiksi jatko-opinnoissa. Etenkin kauan sitten perusopintonsa päättäneiden jatko-opiskelijoiden tukitoiveet saattavat olla korkeat (Lenz 1997). Kluever (1997) tarkasteli monenlaisia avun ja esteiden muotoja, jotka liittyivät sekä jatko-opiskelijan toimintaympäristöön ja omaan toimintaan että ohjaajien, rahoituksen ja lähipiirin rooliin jatko-opiskelun tukemisessa. Hänen tutkimuksessaan korostui perhepiirin emotionaalinen tuki ja tutkimustyön luonne yksinäisenä työnä. Kluever vertaili valmistuneita ja keskeneräisiä ja havaitsi tuen ja esteiden muuttujien eroja, mutta näiden yhteyksiä ei tilastollisesti testattu.

\section{Tutkimuksen ja jatko-opintojen edistyminen}

Suoriutumista ja jatko-opintojen etenemistä on em. tutkimuksissa käsitelty monin eri tavoin. Resursseja ja tukea koskevia muuttujia on saatettu analysoida eri tavoin suoriutuneiden erilaisten ryhmien - valmistuneiden ja keskeneräisten - sisällä tai kesken. Suoriutumista ja etenemistä on arvioitu esim. tutkintoon kuluvana aikana (Seagram et al. 1998, Ferrer de Valero 2001), tutkinnon tavoitteellisena kestona (Tekniikan Akateemisten Liitto TEK 2001), artikkelituotantona (Stack 2004), väitöstyön epäonnistumisena, opintojen keskeyttämisenä tai keskeytysasteena (Golde 1998, 2005, Green 1997), tutkijantaitojen ja työelämätaitojen koettuna kehittymisenä (Hiltunen ja Pasanen 2006, Vuolanto ja Pasanen 2007), arvomaailman kehittymisenä ja uranäkyminä (Hiltunen ja Pasanen 2006) sekä jatkotutkinnon vaatimien kurssien suorittamisena, väitöskirjaehdotuksen jättämisenä ja väitöstutkinnon saamisena (Girves ja Wemmerus 1988).

Aikaisemmassa tutkimuksessa siis painottuvat ihanteelliset, absoluuttiset tulosmittarit - opintoviikot, tutkinnon valmistuminen, artikkelituotanto, arvio opintojen kestosta, saavutetut valmiu- 
det. Ne soveltuvat hyvin ohjelmamaiseen, tavoitteiltaan yhdenmukaiseen jatko-opinto-ohjelmaan ja kuvaavat tuloksia suhteessa ennalta asetettuihin päämääriin. Opintojen aikaisia, keskeneräisiä etenemiskokemuksia on käsitelty vähemmän. Vuolanto ja Pasanen (2007) havaitsivat, että sivutoimisten jatko-opiskelijoiden kokemukset saavutetuista tutkija- ja työelämätaidoista olivat päätoimisia heikommalla tasolla. Tutkimuksen kohteena olivat nimenomaan jatko-opiskelijat, joiden opinnot olivat kesken. Samoin Hiltunen ja Pasanen (2006) tunnistivat päätoimisten ja sivutoimisten välisiä eroja saavutetuissa valmiuksissa. Ko. tutkimuksissa vertailtiin eri ryhmiä, mutta ei varsinaisesti selvitetty resurssien ja ohjauksen yhteyttä tutkimuksen etenemiseen tai valmiusmuuttujiin.

Aiempi tutkimus ei ole käsitellyt sitä, millä tavoin jatko-opiskelijan itse vaikutettavissa olevat asiat kuten ajankäyttö ja muut tuen muodot kuin henkilökohtainen ohjaus voivat olla yhteydessä niihin kokemuksiin, joita opiskelijalla itsellään on omasta (keskeneräisestä) edistymisestään. Sivutoimiseen jatko-opiskeluun tarvitaan sellaisia arviointitapoja, jotka ottavat huomioon opiskelijan omat päämäärät ja valmiudet. Etenkin keskeneräisen jatkoopiskelijan tyytyväisyys omaan etenemiseensä ei välttämättä ole ihanteellisen systeemin mukainen, vaan jatko-opiskelun myönteisenä välituloksena voi olla opiskelijan oma arvio etenemisestään, joka voi välillisesti edistää työtä oikealla tavalla ennen valmistumista.

\section{Tutkimusongelma}

Tutkimuksen tarkoituksena oli selvittää, mitkä tekijät selittävät sivutoimisten, jatko-opinnossaan keskeneräisten opiskelijoiden omaa käsitystä jatko-opiskelun edistymisestä, ja tällä tavoin etsiä keinoja jatkokoulutuksen kehittämiselle.

Tutkimuskirjallisuuden perusteella päätettiin tarkastella seuraavia kolmea mahdollista selittävää tekijää:

a) henkilön taustatekijät, esimerkiksi sukupuoli, lasten määrä ja etäisyys jatko-opintojen käynnistämisestä

b) henkilön omat voimavarat, etenkin ajankäyttö ja jatko-opiskelun suhde varsinaiseen ansiotyöhön

c) henkilön kokemus saamastaan tuesta, esimerkiksi ohjauksesta ja vertaisryhmien tuesta.

Tutkimus keskittyy Teknillisen korkeakoulun Tuotantotalouden osaston keskeneräisiin jatko- opiskelijoihin, joiden valmistumisaika on venymässä selvästi yli Suomessa suositellun neljän jatkoopiskeluvuoden. Viivästymä voidaan kuitenkin ymmärtää ympäristössä, jossa sivutoiminen jatkoopiskelu on enemmän sääntö kuin poikkeus. Tutkimuksen kohderyhmässä sivutoiminen jatkoopiskelu on tyypillistä, sillä suuri osa jatkoopiskelijoista työskentelee tutkijayhteisön ulkopuolella teollisuudessa. Opintojen toteuttaminen on tehty mahdolliseksi henkilökohtaisesti sovittavan jatko-opintokokonaisuuden, yksilöllisten opintosuoritteiden mahdollisuuden ja joustavien toteutustapojen kautta.

\section{Tutkimusmenetelmät}

\section{Tutkimusasetelma ja -aineisto}

Tutkimus toteutettiin lomakekyselynä. Kyselytutkimuksen katsottiin soveltuvan opiskelijamäärältään suureen kohderyhmään ja tutkimustehtävään, jossa haluttiin etsiä jatko-opiskelun edistymiskäsityksiä selittäviä tekijöitä uudessa, sivutoimisten ja keskeneräisten jatko-opiskelijoiden kohderyhmässä. Mahdollisia selittäviä tekijöitä oli jo ennalta tunnistettu aiemman tutkimuskirjallisuuden pohjalta toisenlaisissa kohderyhmissä.

Tämän tutkimuksen kohderyhmänä olivat kaikki Teknillisen korkeakoulun Tuotantotalouden osaston jatko-opiskelijat, jotka ovat aloittaneet jatko-opintonsa vuonna 2001 tai sitä aiemmin ja jotka eivät vielä ole väitelleet. Tällaisia opiskelijarekisterissä olevia jatko-opiskelijoita tunnistettiin 460. Näistä 183 (40 \%) oli ilmoittautunut läsnä olevaksi ja 277 (60 \%) ei ollut ilmoittautunut läsnä olevaksi lukuvuodelle 2005-2006. Koko otoksesta 77 henkilön (16,7 \%) kyselykaavake palautui lähettäjälle Postin viestillä "osoite tuntematon” tai "osoite muuttunut".

Yhteensä 98 jatko-opiskelijaa palautti täytetyn kyselylomakkeen (21 prosenttia lähetetyistä, 26 prosenttia perille menneistä). Vastaajamäärää voidaan pitää vähintäänkin hyvänä, sillä kysely oli kohderyhmälle ainutkertainen, se oli melko laaja ja työläs, ja vastauksia pyydettiin vain kerran. Vastausprosentti on samaa suuruusluokkaa kuin tekniikan alan laajemmassa tutkimuksessa, jossa osaa vastaamatta jättäneistä muistutettiin muistutuskirjeellä (Tekniikan akateemisten liitto TEK 2001). Vastanneiden ryhmä on kuitenkin Tuotantotalouden osaston keskeneräisten jatkoopiskelijoiden populaatioon nähden hieman vinoutunut. Taulukossa 1 esitetään frekvenssit 
Taulukko 1. Vastaajien taustatiedot

\begin{tabular}{|llllllll|}
\hline Ikäryhmä & $\%$ & $\begin{array}{l}\text { Lasten } \\
\text { määrä }\end{array}$ & $\%$ & $\begin{array}{l}\text { Aikaa perus- } \\
\text { tutkinnosta }\end{array}$ & $\begin{array}{l}\text { Aikaa } \\
\text { jatko-opintojen } \\
\text { aloittamisesta }\end{array}$ & $\%$ \\
\hline 20-30 vuotta & 4,1 & 0 & 39,8 & alle 5 vuotta & 5,1 & alle 5 vuotta & 36,7 \\
$31-40$ vuotta & 41,8 & 1 & 18,4 & $5-10$ vuotta & 24,5 & $5-10$ vuotta & 37,8 \\
41-50 vuotta & 29,6 & 2 & 28,6 & $11-20$ vuotta & 33,7 & $11-20$ vuotta & 18,4 \\
$51-60$ vuotta & 17,3 & 3 & 7,1 & $21-30$ vuotta & 20,4 & $21-30$ vuotta & 3,1 \\
yli 60 vuotta & 6,1 & 4 & 2,0 & yli 30 vuotta & 15,3 & yli 30 vuotta & 2,0 \\
tieto puuttuu & 1,0 & tieto & 4,1 & tieto puuttuu & 1,0 & tieto puuttuu & 2,0 \\
& & puuttuu & & & & & \\
\hline
\end{tabular}

vastaajien taustatiedoista.

Profiililtaan miesvaltainen (60,2\%), keski-ikäistyvä ja yli 10 vuotta sitten perustutkintonsa suorittanut, viimeisen 10 vuoden aikana jatkoopintonsa aloittanut vastaajajoukko edustanee populaatiossa tuoreempaa, opinnoissa läsnä olevaa ja aktiivisempaa äärilaitaa. Koska läsnäolevat ilmoittautuvat vuosittain korkeakoululle osoitetietoineen, kysely on todennäköisesti saavuttanut heidät paremmin kuin ilmoittautumatta jättäneet poissaolijat, joiden osoite on vuosien varrella saattanut muuttua. Koko populaatiossa on yli 10 vuotta sitten jatko-opintonsa aloittaneita enemmän kuin otoksessa, sillä hakijoita on alettu karsia vasta 1990-luvun puolivälissä hakijamäärän kasvun myötä ja vuotuiset valmistumismäärät eivät ole juuri muuttuneet. Vastaajajoukko myös edustaa tavoiteltua yliopistosta etääntynyttä ryhmää hyvin: yli 70 prosentilla on perustutkinnon suorittamisesta kulunut yli 10 vuotta. Vastaamatta jättäneiden ja osoitemuutosten takia kadonneiden jatko-opiskelijoiden joukko edustanee poissaolevia, passiivisia ja jopa keskeyttämispäätöksen jo tehneitä jatko-opiskelijoita.

Verrattuna tekniikan alan jatko-opiskelijoihin (TEK Tekniikan akateemiset 2001) tämän tutkimuksen otoksessa on enemmän naisia, enemmän yli 40 vuotiaita, enemmän lapsiperheellisiä, ja enemmän yli 20 vuotta sitten perustutkintonsa päättäneitä. Nämä erityispiirteet ovat tuotantotalouden poikkitieteellisyyden ja sivutoimisen opiskelun näkökulmasta tämän tutkimuksen kohderyhmälle tyypillisiä.

\section{Muuttujat ja aineiston analyysi}

Lomakekysely kehitettiin käytännön tarpeeseen löytää keinoja keskeneräisten jatko-opintojen edistämiseen. Vaikka kyselyn muuttujat voidaan tunnistaa myös aikaisemmassa jatko-opiskelua kos- kevassa tutkimuksessa, kyselyn kysymykset luotiin yhteistyössä osaston henkilökunnan kanssa. Jokaista muuttujaa varten esitettiin 3 - 5 kysymystä. Riippumattomissa ja riippuvissa muuttujissa käytettiin pääosin Likert-asteikkoa 1 (täysin eri mieltä)...5 (täysin samaa mieltä). Taustamuuttujien skaalat esitetään taulukossa 1 , ja resurssimuuttujien skaalat ovat järjestysasteikollisia, taulukko 2. Kaikki yhdistelmämuuttujien sisältämät väittämät esitetään liitteessä 1.

Riippuvana muuttujana on tutkimuksen edistyminen, jolla tarkoitetaan jatko-opiskelijan omaa kokemusta siitä, miten jatko-opinnäytteen vaatima tutkimus on edennyt. Muuttuja koostui neljästä väittämästä, esimerkiksi "Tutkimukseni on edennyt suunnitelmieni mukaan” ja "Olen tyytyväinen tutkimukseni tuloksiin tässä vaiheessa”.

Riippumattomat muuttujat voidaan jakaa kahteen ryhmään: henkilökohtaisia voimavaroja koskeviin muuttujiin ja koettua tukea koskeviin muuttujiin. Voimavaramuuttujat ovat yksittäisiä kysymyksiä, joilla haluttiin selvittää opiskelijan todelliset ajankäyttömahdollisuudet jatko-opiskeluun ja tutkimuksen tekemiseen. Näitä olivat: Ansiotyöhön kuluva aika, Opiskeluun käytetty aika, Tutkimukseen käytetty aika ja Opiskeluun ja tutkimukseen käytetty ansiotyöaika. Skaalat olivat kategorisia (taulukko 2), järjestysasteikollisia (1...3 tai 1...4) ja kategoriat perustuvat viikottain em. asioihin käytettyihin tuntimääriin. Tekniikan Akateemisten Liitto TEK:in (2001) tutkimuksesta poiketen tässä tutkimuksessa haluttiin eritellä tutkimukseen käytetty aika opiskeluun käytetystä ajasta myös suhteessa ansiotyöhön käytettyyn aikaan.

Tukimuuttujissa tiedusteltiin neljää erilaista tukimuotoa. Ohjaajien tuki koskee esimieheltä, työn valvojalta ja ohjaajalta saatua tukea ja sen riittävyyttä ja sisältää 4 väittämää. Vertaistuki 
koskee muiden jatko-opiskelijoiden ja tiedeyhteisöltä saatavaa tukea ja sisältää 4 väittämää. Työn antama tuki koskee varsinaisen palkkatyön ja opiskelun ja tutkimuksen keskinäisiä hyötyjä ja sisältää 4 väittämää. Omat valmiudet sisältävät tutkijan oman työpanoksen tutkimuksen edistämiseksi, ongelmien ratkaisuksi ja tarvitsemansa tiedon omaksumiseksi ja sisältää 5 väittämää. Näitä muuttujia läheisesti vastaavaa käsitteellistämistä ja kysymyksenasettelua on esitetty mm. helphindrance-skaalassa (esim. Kluever 1997) ja useissa muissa aiemmissa tutkimuksissa (mm. Seagram et al. 1998, Herrala 1999, Ferrer de Valero 2001, Girves ja Wemmerus 1988, Weidman ja Stein 2003, Hiltunen ja Pasanen 2006).

Tutkimusaineisto-kappaleessa mainitut yksilökohtaiset taustamuuttujat sukupuoli, ikäryhmä, lasten määrä, aika perustutkinnosta ja aika jatkoopintojen aloittamisesta otetaan huomioon kontrollimuuttujina.

Aineiston analysoinnissa tarkastellaan kuvailevaa tilastotietoa (keskiarvot, hajonnat, frekvenssit, korrelaatiot), ja varsinainen analyysi toteutettiin lineaarisena regressiona. Aineisto soveltui tällaiseen tarkasteluun erinomaisesti: alustavassa hajontakaavioiden tarkastelussa havaittiin selkeät lineaariset suhteet riippumattomien ja riippuvan muuttujan välillä, ja muuttujien multikollineaarisuus ei ollut ongelma.

\section{Tutkimuksen validiteetti}

Tutkimuksen kohdeorganisaationa oli Teknillisen korkeakoulun Tuotantotalouden osasto, jolla sivutoiminen jatko-opiskelu on tyypillistä ja mahdollista ja jonka tutkimusalat kattavat laajan teollis-kaupallis-humanistisen kentän. Populaatio ja vastaajaryhmä kohdeorganisaatiossa siis poikkeaa esimerkiksi sukupuolijakaumansa ja perustutkinnon valmistumisajankohdan osalta teknillisen alan laajemmasta populaatiosta. Tutkimuksella on etsitty ensisijaisesti kehitysideoita osaston tarpeisiin, ja yleistettävyydeltään tulokset palvelevat juuri poikkitieteellisiä osastoja ja laitoksia, joilla voi opiskella sivutoimisesti. Kyselyn vastaajajoukossa havaittu vinoutuma viittaa siihen, että löydökset kohdistuvat erityisesti viimeisen kymmenen vuoden aikana aloittaneisiin, läsnä oleviin ja aktiivisiin jatko-opiskelijoihin, eivätkä päätelmät välttämättä koske passiivisimpia ja poissa olevia jatko-opiskelijaryhmiä.

Tutkimus toteutettiin lomakekyselynä, jonka sisällöt nostettiin esille aiemman kirjallisuuden perusteella ja jonka muuttujat valmisteltiin osaston asiantuntijaryhmässä. Rajauduimme jatkoopiskelijaa lähellä oleviin ilmiöihin kuten hänen omaan ajankäyttöönsä ja hänen kokemaansa tukeen. Jätimme tietoisesti tutkimuksen ulkopuolelle esimerkiksi jatko-opintojen rahoitusratkaisut ja tiedekunnan viralliset prosessit, vaikka nekin ovat tärkeitä tutkimusaiheita ja kehityskohteita.Tutkimuksen edistymistä selittävien tekijöiden viitekehys perustui aiempaan tutkimukseen, jota tällä tutkimuksella haluttiin täydentää juuri sivutoimisten jatko-opiskelijoiden kohdalla ja valikoiduin rajauksin.

Muuttujarakenteen validiteettia testattiin eksploratiivisella faktorianalyysillä (pääkomponenttianalyysi, varimax-rotaatio), ja muuttujien reliabiliteettia arvioitiin Cronbachin alphan sisäisen konsistenssin kertoimella. Alustava faktorirakenne toimii hyvin, sen selitysvoima on lähes 70 prosentin vaihtelusta, ja tämä antaa tukea yhdistelmämuuttujien käytölle. Lievät päällekkäisyydet etenkin Tutkimuksen edistyminen ja Omat valmiudet -muuttujissa kannustavat kuitenkin muuttujien jatkokehittämiseen. Muuttujille lasketut Cronbachin Alpha -reliabiliteettikertoimet ovat välillä 0,82 (Tutkimuksen edistyminen) ja 0,92 (Työn antama tuki), mikä kertoo erittäin hyvästä muuttujan sisäisestä johdonmukaisuudesta.

\section{Tulokset: Tutkimuksen edistymisen ja resurssien väliset yhteydet}

Taulukossa 2 on ajankäyttömuuttujien frekvenssit prosenttiosuuksina. Taulukon 2 tuloksista käy ilmi, että vastaajajoukon varaamat ajalliset resurssit opintojen ja tutkimuksen tekemiseen ovat varsin vähäiset. Yli 86 prosenttia vastaajista käyttää opiskeluun alle työpäivän verran (0-8 tuntia) viikoittaista aikaansa, ja yli 76 prosenttia vastaajista käyttää tutkimuksen tekemiseen alle työpäivän viikossa. Aiemmassa, laajemmassa tekniikan alan tutkimuksessa on saatu vastaavia tuloksia (Tekniikan Akateemisten liitto 2001). Yli 60 prosenttia vastaajista tekee ansiotyötä, joka vaatii yli 40 tunnin viikoittaisen ajankäytön. Vain 15 prosenttia pystyy käyttämään yli päivän verran varsinaisesta ansiotyöajastaan opiskeluun ja tutkimukseen.

Liittessä 2 esitetään muuttujien keskiarvot, keskihajonnat ja korrelaatiokertoimet. Vastaajat kokevat saavansa melko heikosti tai kohtalaisesti tukea opiskelussaan ja tutkimuksessa. Vastaavaa, heikohkoa ja kohtalaista ohjauksen kokemusta ja 
Taulukko 2. Ajankäyttömuuttujien frekvenssit prosenttiosuuksina (n=98).

\begin{tabular}{|c|c|c|c|c|c|c|c|}
\hline \multicolumn{2}{|c|}{ kuluva aika/vko } & $\begin{array}{l}\text { Opiskeluun } \\
\text { käytetty aika } \\
\text { /vko }\end{array}$ & $\%$ & $\begin{array}{l}\text { Tutkimukseen } \\
\text { käytetty aika } \\
\text { /vko }\end{array}$ & $\%$ & $\begin{array}{l}\text { Opiskeluun ja } \\
\text { tutkimukseen käy- } \\
\text { tetty ansiotyöaika }\end{array}$ & $\%$ \\
\hline & & & & & & Ivko & \\
\hline $0-19 h$ & 11,2 & $0-8 \mathrm{~h}$ & 86,7 & $0-8 \mathrm{~h}$ & 76,5 & ei ollenkaan & 39,8 \\
\hline $20-39 h$ & 24,5 & $9-19 h$ & 7,1 & $9-19 h$ & 15,3 & alle $8 \mathrm{~h}$ & 40,8 \\
\hline $40-59 h$ & 49,0 & yli 20 h & 2,0 & yli 20 h & 5,1 & $9-19 \mathrm{~h}$ & 8,2 \\
\hline yli 60 h & 12,2 & ei vastausta & 4,1 & ei vastausta & 3,1 & yli 20 h & 7,1 \\
\hline ei vastausta & 3,1 & & & & & ei vastausta & 4,1 \\
\hline
\end{tabular}

ohjauksen piiriin hakeutumista on havaittu aiemmassa, laajemmassa tutkimuksessa (Tekniikan Akateemisten Liitto TEK 2001). Työstä saatu tuki on koettu hieman korkeammaksi kuin ohjaajalta, vertaisryhmistä tai omista valmiuksista saatu tuki. Vastaajien tyytyväisyys tutkimuksen edistymiseen on vähäistä.

Taustatiedot eivät juuri korreloi muiden muuttujien kanssa (liite 2). Poikkeuksena aika jatko-opintojen aloittamisesta korreloi merkitsevästi ja negatiivisesti kaikkien tukimuuttujien sekä tutkimuksen edistymisen kanssa. Tämä kertoo tiedeyhteisön etääntymisestä monin tavoin: mitä kauemman aikaa kuluu, sitä vaikeampi jatko-opiskelijan on liittyä akateemiseen yhteisöön ja sitä heikommat ovat myös edistymiskokemukset. Ansiotyöhön kuluva aika korreloi negatiivisesti tutkimukseen käytetyn ajan kanssa: runsaasti aikaa vievä työ näyttää heikentävän tutkimuksen tekemistä yleisesti samoin kuin työajan käyttöä opintoihin tai tutkimukseen. Voimavaramuuttujilla on joitakin merkitseviä korrelaatioita tuki- ja edistymismuuttujien kanssa. Esimerkiksi tutkimukseen käytetty aika korreloi merkitsevästi ja positiivisesti vertaisryhmän tuen, omien valmiuksien ja tutkimuksen edistymisen kanssa. Aikainvestointi konkretisoituu tällä tavoin tutkijan omana työnä. Pääosa tukimuuttujista korreloi keskenään ja tutkimuksen edistymisen kanssa.

Selvitimme eri tekijöiden osuutta ja selitysvoimaa jatko-opintojen edistymiskokemuksissa kolmevaiheisella lineaarisella regressioanalyysillä (taulukko 3). Ensimmäisessä vaiheessa malliin otettiin vain kontrollimuuttujat. Mallin selitysvoima on melkein merkitsevä, mutta erittäin alhainen. Vain Aika jatko-opintojen aloittamisesta selittää merkitsevällä tasolla edistymiskokemusta: mitä kauemman jatko-opintojen aloittamisesta on, sitä heikommat edistymiskokemukset.

Toisessa vaiheessa malliin lisättiin opiskelijan oma ajankäyttö. Toisen mallin selitysvoima on erittäin merkitsevä ja kohtalainen (28\%), ja merkitseväksi, myönteisesti riippuvaan muuttujaan vaikuttavaksi tekijäksi ilmenee Tutkimukseen käytetty aika. Mitä enemmän tutkimukseen käytetään aikaa, sen korkeampi on kokemus tutkimuksen edistymisestä. Toisessa mallissa Aika jatko-opintojen aloittamisesta ei enää vaikuta riippuvaan muuttujaan, ts. ajankäyttöinvestoinnit tutkimukseen vähentävät kuluvan ajan merkitystä edistymiskokemuksissa.

Kolmannessa mallissa lisättiin koettua tukea koskevat muuttujat. Mallin selitysvoima on erittäin merkitsevä ja korkea (73\%), ja uusiksi riippuvaan muuttujaan yhteydessä oleviksi tekijöiksi osoittautuvat Työn antama tuki ja Omat valmiudet. Työn antaman tuen ja Omien valmiuksien vaikutus on erityisen voimakas. Kolmannessa mallissa Aika jatko-opintojen aloittamisesta on nyt positiivisessa ja melkein merkitsevässä yhteydessä tutkimuksen etenemiseen. Toisin sanoen tuen myötä ajallinen etäisyys tuleekin myönteiseksi, hyödylliseksi tekijäksi. Ohjaajien tuki tai Vertaisryhmän tuki ei ole tilastollisesti merkitsevällä tasolla yhteydessä edistymiskokemuksiin.

\section{Pohdintaa ja päätelmiä}

Tutkimuksemme lähtökohtana oli tohtoriopintojen houkuttelevuuden kasvu, sivutoimisen jatkoopiskelun saama vähäinen huomio jatkokoulutuksen säätelyssä ja ohjeistuksessa sekä lisääntyvä tutkimuksellinen ja käytännöllinen kiinnostus sivutoimisiin jatko-opintoihin. Tutkimuksen kohdeorganisaatiossa sivutoiminen, asiantuntijuuden syventämiseen tähtäävä jatko-opiskelu on ottanut merkittävän sijan päätoimisen, tutkijauralle suuntaavan jatko-opiskelun rinnalla. Sivutoimiseen jatkokoulutukseen liittyy kuitenkin huoli pitkistä aikatauluista, hitaasta etenemisestä ja ohjaukseen 
Taulukko 3. Tutkimuksen edistymistä selittävät tekijät: regressioanalyysin tulokset

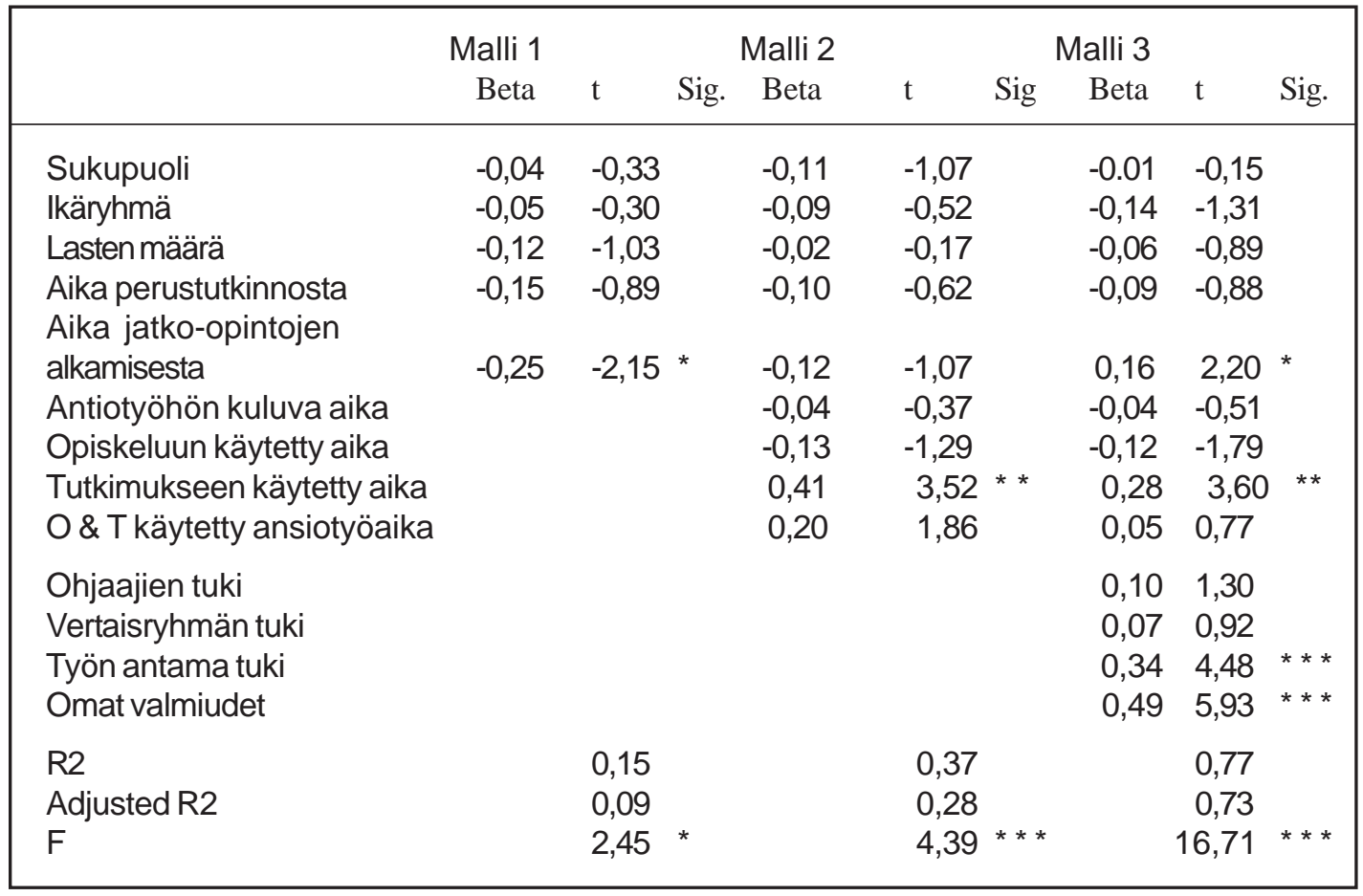

${ }^{*} p<0,05,{ }^{* *} p<0,01,{ }^{* * *} p<0,001$

käytettyjen voimavarojen tuloksellisuudesta. Tavoittelimme ymmärrystä siitä, millä tavoin sivutoimisten jatko-opiskelijoiden väylää kannattaisi kehittää ja miten keskeneräisiä opintoja kannattaisi tukea. Halusimme selvittää, mitkä tekijät selittävät sivutoimisten jatko-opiskelijoiden käsityksiä tutkimuksen edistymisestä opintojen vielä ollessa kesken, ja löysimme näitä tekijöitä henkilön taustatekijöistä, omasta ajankäytöstä ja koetusta tuesta.

Taustatekijät. Tutkimuksemme näyttää, että pitkä ajallinen etäisyys jatkotutkinnon aloittamisen ja nykyhetken välillä on yhteydessä jatkoopiskelijan käsityksiin tutkimuksen vähäisestä edistymisestä. Tämä negatiivinen yhteys poistuu, jos jatko-opiskelija itse investoi tutkimukseen ajallisia voimavarojaan. Edelleen työelämäkokemus näyttää olevan eduksi tutkimuksen etenemiselle tilanteessa, jossa jatko-opiskelija kokee työnsä tukevan jatko-opintoja ja omaa riittävät valmiudet oman jatko-opiskelunsa edistämiseen. Tulokset antavat ymmärtää, että myös hitaat, työelämälähtöiset jatko-opinnot voidaan kokea mielekkäiksi ja että opiskelijan omassa toiminnassa on avaimet tämän mielekkyyden aikaansaamiseen. Vastoin kirjallisuuskatsauksessa esiteltyä aiempaa tutkimusta esimerkiksi sukupuoli, lasten määrä tai etäisyys perusopinnoista ei ollut yhteydessä tutkimuksen edistymiseen, mikä voi selittyä subjektiivisen tutkimuksen edistymistä kuvaavan muuttujan käytöllä (opintoviikkojen tai tutkintojen sijasta).

Oma ajankäyttö. Kyselytutkimuksemme osoittaa, että sivutoimisen jatko-opiskelijan todelliset jatko-opintoresurssit paljon energiaa ja aikaa vievän ansiotyön rinnalla ovat kaukana päätyökseen tutkimusta tekevän resursseista. Muutaman viikoittaisen opiskelu- ja tutkimustunnin investointi jatko-opiskeluun vastaa aikaisempaa tutkimusta (Tekniikan Akateemisten Liitto TEK 2001) ja merkitsee sitä, että neljän vuoden tavoiteaikataulu on sula mahdottomuus. Regressioanalyysi kuitenkin osoitti, että tutkimukseen käytetty aika oli myönteisessä yhteydessä tutkimuksen edistymiskokemuksiin ja että ansiotyön vaatima aika ei varsinaisesti heikentänyt edistymiskokemuksia. Sivutoimisille jatkoopiskelijoille olisi asetettava resurssi-investointiin nähden kohtuulliset ajalliset tavoitteet sen sijaan, että vaaditaan jo lähtökohtaisesti mahdotonta neljän vuoden aikataulua. Tulokset nostavat samalla esille kysymyksen siitä, voiko kymmenek- 
si tai kahdeksikymmeneksi vuodeksi venyvä jatkoopintojen taival johtaa sellaiseen uuden tiedon luomiseen ja jatkotutkimuksen valmiuksiin, jota tuoreelta tohtorilta edellytetään.

Koettu tuki. Tutkimuksemme osoittaa sivutoimisuuteen sisältyvän mahdollisuuden: katkeamaton resurssi-investointi ja etenkin työn antama tuki (myös Tekniikan Akateemisten Liitto TEK 2001) ja oman aktiivisuuden myötä syntyvä tuki (tai itseohjaus, ks. Herrala 1999) antaa keskeneräisille jatko-opiskelijoille myönteisiä edistymiskokemuksia, joiden varassa pitkäksi venyvä taival vähintäänkin ruokkii elinikäistä oppimista ja voi tulla lopulta ainakin yksilötasolla tulokselliseksi. Sen sijaan aiemmassa tutkimuksessa vahvasti korostuneet ohjaajan ja vertaisryhmän tuki eivät tässä sivutoimisten, keskeneräisten jatkoopiskelijoiden aineistossa olleet suoraan yhteydessä edistymiskokemuksiin. Tämä on selkeä poikkeama ja löydös aikaisempiin päätoimisia jatkoopintoja koskeviin tutkimuksiin nähden. Voimme ymmärtää tulokset käytännöllisessä mielessä: etenkin sivutoimisessa jatko-opiskelussa opiskelijan on oltava aktiivinen hakeutuakseen tiedeyhteisön ja sen ohjauksen piiriin ja tuotettava henkilökohtaisen tuen edellyttämiä kirjallisia välituotoksia, kun taas poissaolo tarkoittaa myös ohjauksen ja tuen poissaoloa.

Tutkimuksen kohdeorganisaatiossa sivutoimiseen jatko-opiskeluun kohdistuu runsaasti kysyntää teollisuudesta, jossa asiantuntijuutta halutaan syventää ansiotyön ohessa opiskellen. Näin ollen on tarpeen soveltaa kahden erilaisen väylän jatkokoulutusmallia. Tällöin sivutoimisten, työelämästä tulevien jatko-opiskelijoiden ohjausta ja opetusta olisi erilaistettava niin, että opiskelijalle syntyisi luonteva, kiinteä ja suorastaan "pakollinen” tapa olla kytköksessä tiedeyhteisöön säännöllisesti (myös Herrala 1999). Etenkin alkuvuosina olisi käytettävä voimavaroja sivutoimisen jatko-opiskelijan tietopohjan ja omien valmiuksien vahvistamiseen sallimalla opiskeluun keskittyminen ilman opinnäytteen tuottamaa lisäpainetta. Tieteellisten perusvalmiuksien kautta tehdään mahdolliseksi opiskelijan oman tutkimuksellisen tahtotilan kirkastuminen ja konkreettisten, ansiotyön kanssa järkevästi yhteensovitettujen välitavoitteiden - esimerkiksi lisensiaatintutkinnon - asettaminen. Edelleen kahden eri väylän mallissa on uudella tavalla varauduttava häiriöihin, joita työelämän paineet ja joustovaatimukset tuovat opiskelijoiden suunnitelmiin. Näin ollen olisi esimerkiksi tunnistettava keskeyttämisen mahdollisuus ja tarve todistaa elinikäistä oppimista esimerkiksi välitodistuksin.

\section{Käytännön kehitystoimenpiteet kohdeorganisaatiolle}

Tutkimuksemme nostaa esille kysymyksen siitä, millä tavoin etenkin sivutoimiseen jatkokoulutukseen suuntautuvat tiedekunnat ja laitokset voivat kehittää toimintaansa sivutoimisen jatko-opiskelun tukemiseksi päätoimisen jatkokoulutusväylän rinnalla. Aikaisempi tutkimus on suositellut sivutoimisen jatko-opintoväylän (tai tutkijakoulujen ulkopuolisen jatkokoulutuksen) suuntaamista ammatillisiin tohtorintutkintoihin (esim. Dill et al. 2006, Vuolanto ja Pasanen 2007) ja tutkintotavoitteiden erilaistamiseen. Itse koemme, että tohtoritutkinnon tutkintovaatimukset kannattaa säilyttää yhdenmukaisina ja kansainvälistä tasoa vastaavina, mutta erilaistamista voitaisiin toteuttaa pää- ja sivutoimisten jatko-opiskelijoiden erilaiset tarpeet ja olosuhteet huomioon ottavissa rinnakkaisissa opintosuunnittelun, ohjauksen ja tuen malleissa. Tutkimuksen kohdeorganisaation käytännön kehitystoimenpiteinä nostamme esille neljä toisiinsa liittyvää asiaa.

1) Kahden erilaisen jatkokoulutusväylän selkeä erilaistaminen. Jotta tohtorikoulutuksen samanlaiset tutkintotavoitteet voisivat täyttyä, voitaisiin päätoimisten ja sivutoimisten jatko-opiskelijoiden opintopolkuja erilaistaa niin, että etenemistapa ottaa huomioon työhön käytetyt resurssit ja työn erilaiset olosuhteet.

2) Kahden jatkotutkinnon järjestelmän vahvistaminen. Etenkin sivutoimisen jatkokoulutettavan pitkä jatko-opintoaikataulu tuo opintoihin epävarmuuksia, joita voitaisiin vähentää tarjoamalla konkreettisia välietappeja jatko-opintoihin. Selkeät välietapit voisi syntyä rakenteellisesti selkeämmistä tutkinto-ohjelmista, opintojen eri moduulien valmistumisesta sekä lisensiaatintutkinnon aktiivisemmasta käytöstä.

3) Erilaisille jatkokoulutusväylille kohdistetut resurssit. Jotta yliopiston voimavarat riittäisivät, tulisi myös rahoitusta ja ohjaus- ja opetustapoja erilaistaa eri jatkokoulutusväylille. Jos kullekin väylälle kohdistettuja resursseja ei pystytä varaamaan, tullee tarpeelliseksi harkita sivutoimisten jatko-opiskelijoiden kiintiöintiä, jotta tohtoriohjelmien tulostavoitteet täyttyvät.

4) Välitulosten tunnustaminen ja keskeyttämisen tekeminen mahdolliseksi. Etenkin sivutoi- 
misen jatko-opiskelijan kohdalla opetuksessa tulisi edistää modulaarisuutta, jossa opiskelija saa tiedon välituloksistaan ja näkee etenemisensä suhteessa tavoitteisiin paremmin. Lisäksi nykyisen ikiopiskelija-järjestelmän sijasta tulisi tehdä mahdolliseksi jatko-opintojen keskeyttäminen ja näin ollen jatkoopiskelijan poistaminen rekisteristä, jotta yliopistoosastot voivat kohdistaa tukea ja voimavaroja aktiivisiin ja todella itsekin työtään edistäviin opiskelijoihin (myös Dill et al. 2006).

\section{Lähteet}

Aittola, H. ja Määttä, P. (1998). Tohtoriksi tutkijakoulusta. Tutkijakoulut tieteellisten jatkoopintojen uudistajina. Tutkimuksia 3. Jyväskylän yliopisto, Koulutuksen tutkimuslaitos.

Austin, A. E. (2002). Preparing the next generation of faculty: graduate school as socialization to the academic career. Journal of Higher Education. Vol. 73 (1), 94-122.

Bargar, R. R. and Mayo-Chamberlain, J. (1983). Advisor and advisee issues in doctoral education. Journal of Higher Education. Vol. 54 (4), 407-432.

Carey, K. T. and Dorn, S. M. (1998). Overcom-ing obstacles through use: a case study. New Directions for Teaching and Learning. Vol. 76(Winter), 67-78.

Dill, D. D., Mitra, S. K., Jensen, H. S., Lehtinen, E. Mäkelä, T., Parpala, A., Pohjola, H., Ritter, M. A. and Saari, S. (2006). PhD training and the knowledge-based society. An evaluation of doctoral education in Finland. Publications of the Finnish Higher Education Evaluation Council 1:2006.

Ferrer de Valero, Y. (2001). Departmental factors affecting time-to-degree and completion rates of doctoral students at one land-grant research institution. Journal of Higher Education. Vol. 72 (3), 341-367.

Girves, J. E. and Wemmerus, V. (1988). Developing models of graduate student degree progress. Journal of Higher Education. Vol. 59 (2), 163-189.

Golde, C. M. (1998). Beginning graduate school: explaining first-year doctoral attri-tion. New Directions for Higher Education. (101, Spring), 55-64.
Golde, C. M. (2005). The role of the department and discipline in doctoral student attrition: lessons from four departments. Journal of Higher Education. Vol. 76 (6), 669-700.

Gordon, P. J. (2003). Advising to avoid or to cope with dissertation hang-ups. Academy of Management Learning and Education. Vol. 2 (2), 181-187.

Green, K. E. (1997). Psychosocial factors affecting dissertation completion. New Directions for Higher Education. (99, Fall), 57-64.

Hakala, J., Kaukonen, E., Nieminen, M. ja Ylijoki, O-H. (2003). Yliopisto - tieteen kehdosta projektimyllyksi? Helsinki: Gaudeamus.

Herrala, M. (1999). Kokemuksia tieteellisten jatko-opintojen ohjauksesta Teknillisen korkeakoulun Tuotantotalouden osastolla - tavoitteeksi suunnitelmallinen ohjaus jatkoopiskelijan kasvun tueksi. Kasvatustieteen pro gradu -tutkielma, Helsingin yliopisto, Kasvatustieteen laitos.

Hiltunen, K. ja Pasanen, H-M. (2006). Tulevat tohtorit. Jatko-opiskelijoiden kokemukset ja arviot tohtorikoulutuksesta 2005. Opetusministeriön julkaisuja 2006: 48.

Husso, K. (2005). Tohtorit, tiedepolitiikka ja työmarkkinat. Tutkijankoulutus Suomessa 1950-luvulta tutkijakoulujen aikaan. Opetusministeriön julkaisuja 2005: 21.

Kivinen, O., Rinne, R. ja Ketonen, K. (1993). Yliopiston huomen. Korkeakoulupolitiikan historiallinen suunta Suomessa. Helsinki: Hanki ja Jää.

Kluever, R. C. (1997). Students' attitudes toward the responsibilities and barriers in doctoral study. New Directions for Higher Education. (99, Fall), 47-56.

Kurri, E. (2006). Opintojen pitkittymisen dilemma. Tutkimus opintojen sujumattomuustekijöistä yliopistoissa ja niihin vaikuttamisen keinoista. Opiskelijajärjestöjen tutkimussäätiö Otus rs 27/2006, Helsinki.

Lenz, K. S. (1997). Nontraditional-aged women and the dissertation: a case study approach. New Directions for Higher Education (99, Fall), 65-74.

Opetusministeriö (2006a). Tohtorikoulutuksen kehittäminen. Opetusministeriön työryhmämuistioita ja selvityksiä 2006:3. 
Opetusministeriö (2006b). Tutkijanuratyöryhmän loppuraportti. Opetusministeriön työryhmämuistioita ja selvityksiä 2006:13.

Opetusministeriön KOTA-tietokanta, internet-sivusto: http://www.minedu.fi/OPM/Koulutus/ yliopistokoulutus/tilastoja/?lang=fi

Seagram, B. C., Gould, J. and Pyke, S. W. (1998). An investigation of gender and other variables on time to completion of doctoral degrees. Research in Higher Education. Vol. 39 (3), 319-335.

Sorenson, G. and Kagan, D. (1967). Conflicts between doctoral candidates and their sponsors: a contrast in expectations. Journal of Higher Education. Vol. 38 (1), 17-24.

Stack, S. (2004). Gender, children and research productivity. Research in Higher Education. Vol. 45 (8), 891-920.

Tekniikan Akateemisten Liitto TEK (2001). Tekniikan alan jatko-opiskelun nykytila ja kehittämistarpeet Suomessa. Tekniikan Akatee- misten Liitto TEK, Helsinki.

Weidman, J. C. ja Stein, E. L. (2003). Socialization of doctoral students to academic norms. Research in Higher Education. Vol. 44 (6), 64156.

Vuolanto, P. ja Pasanen, H-M. (2007). Toteutuuko tohtorikoulutus paremmin tutkijakouluissa kuin niiden ulkopuolella? Tiedepolitiikka (3), 7-21.

Väyrynen, R. (2003). Yliopistot pitävät pintansa, yliopistoina. Helsingin Sanomat 17.9.2003.
Artikkeli saapui toimitukseen 3.5.2007. Se hyväksyttiin julkaistavaksi 30.1.2008.

Liite 1. Muuttujat, niiden sisältämät väittämät, faktorirakenne ja luotettavuuskertoimet

\section{Ohjaajien tuki}

Saan riittävästi tukea esimieheltäni

Saan riittävästi tukea valvojaltani

Saan riittävästi tukea ohjaajaltani

Pyytäessäni olen saanut tukea suunnitteluun

\section{Vertaistuki}

Tunnen hyvin muita jatko-opiskelijoita

Olen aktiivisesti yhteydessä muihin jatko-opiskelijoihin

Tunnen oman alani tiedeyhteisön vaikuttajia

Osallistun aktiivisesti tutkimusalan tiedeyhteisön toimintaan

Työn antama tuki

Opiskelu tuottaa selkeitä hyötyjä nykyiseen työhöni Cronbachin Alpha

Tutkimuksen tekeminen tuottaa selkeitä hyötyjä työhöni

Nykyiset työtehtäväni edistävät opintojani

Nykyiset työtehtäväni edistävät tutkimuksen tekemistä

\section{Omat valmiudet}

Olen käytettänyt riittävästi aikaa tutkimuksen tekemiseen

Olen saanut ratkaistua tutkimuksen aikana esiin nousseet ongelmat

Kaikki tutkimukseni kannalta oleellinen tieto on saatavillani

Minulla on kaikki tarvittava metodiosaaminen tutkimuksen tekemiseen

Olen saanut tarvitsemani sisällöllisen ohjauksen

\section{Tutkimuksen edistyminen}

Tutkimukseni on edennyt suunnitelmieni mukaan

Olen tyytyväinen tutkimukseni edistymiseen

Olen tyytyväinen tutkimukseni tuloksiin tässä vaiheessa

Opinnäytetyöni valvoja on ollut tyytyväinen tutkimukseni sisältöön
0,85

Faktorilataus

0,70

0,89

0,74

0,74

0,86

0,90

0,86

0,56

0,65

0,92

0,83

0,91

0,89

0,83

0,83

0,59

0,78

0,66

0,86

0,71

0,82

0,88

0,92

0,89

0,56 
Liite 2. Taustatietojen, henkilökohtaisen ajankäytön, tuen ja tutkimuksen edistymisen

keskiarvot, keskihajonnat ja Pearson-korrelaatiot.

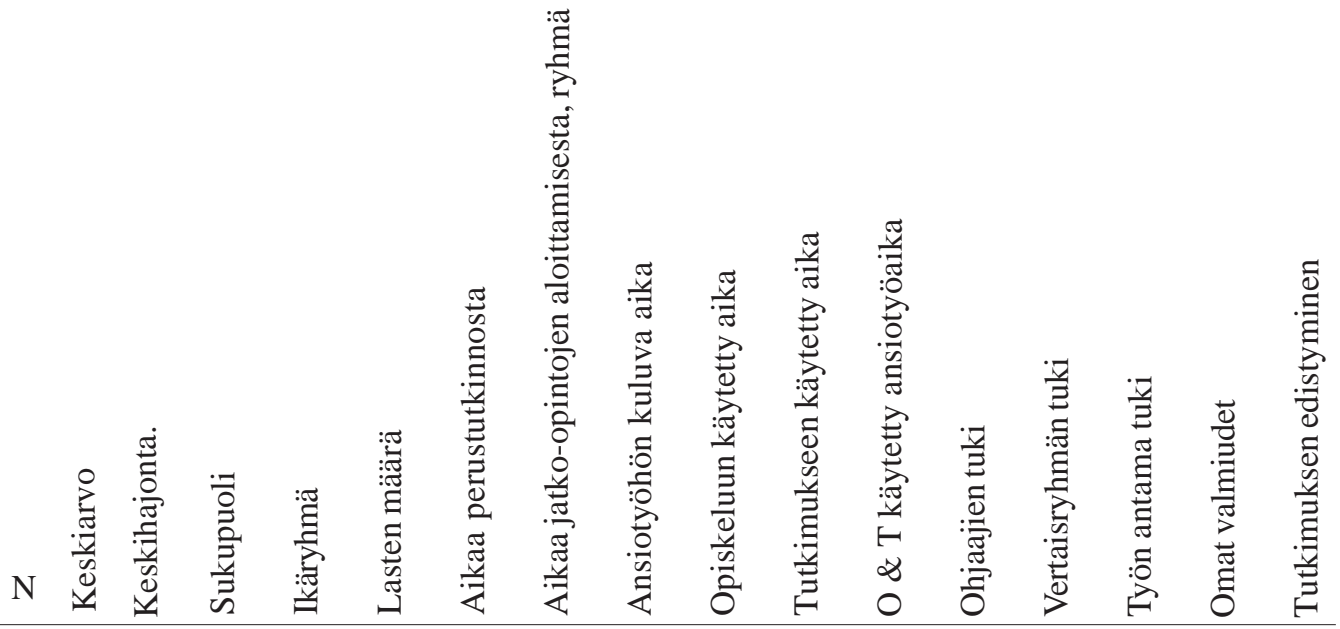

Sukupuoli $\quad 97 \quad 0,39 \quad 0,49$

Ikäryhmä $\quad 97 \quad 2,79 \quad 0,99-0,24 *$

Lasten määrä $94 \quad 1,10 \quad 1,10 \quad 0,05 \quad-0,20$

Etäisyys perus-

tutkinnosta $\quad 97 \quad 3,16 \quad 1,12-0,08 \quad 0,75$ **-0,07 $^{-0}$

Etäisyys jatko-

opintojen

aloittamisesta $96 \quad 1,94 \quad 0,94-0,06 \quad 0,32 * * 0,04 \quad 0,30 * *$

Ansiotyöhön

kuluva aika

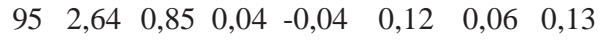

Opiskeluun

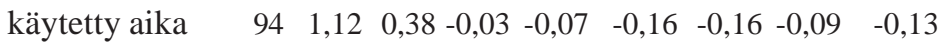

Tutkimukseen

käytetty aika $95 \quad 1,27 \quad 0,590,13 \quad-0,13 \quad-0,24 *-0,12 \quad-0,31^{* *}-0,33 * * 0,19$

O \& T käytetty

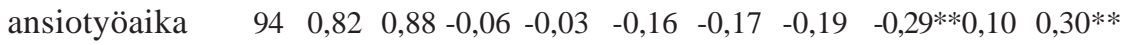

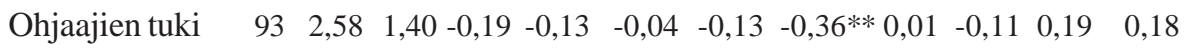

Vertaisryhmän

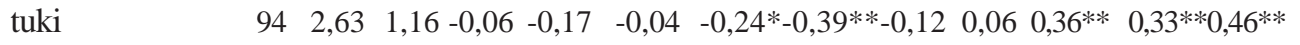

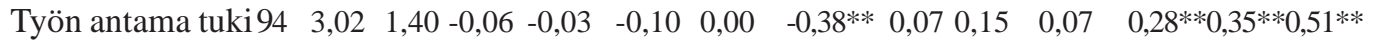

$\begin{array}{llllllllllllll}\text { Omat valmiudet } & 83 & 2,66 & 1,12 & -0,07 & 0,01 & -0,03 & -0,04 & -0,24 * & -0,27 * 0,01 & 0,37 * * & 0,29 * * 0,46 * * & 0,45 * * & 0,20\end{array}$

Tutkimuksen

edistyminen $832,07 \quad 1,20-0.01-0,22 *-0,14 \quad-0,23 *-0,30 * *-0,25 * 0,02 \quad 0,48 * * 0,38^{* *} 0,44^{* *} 0,55^{* *} 0,43 * * 0,74 * *$ 